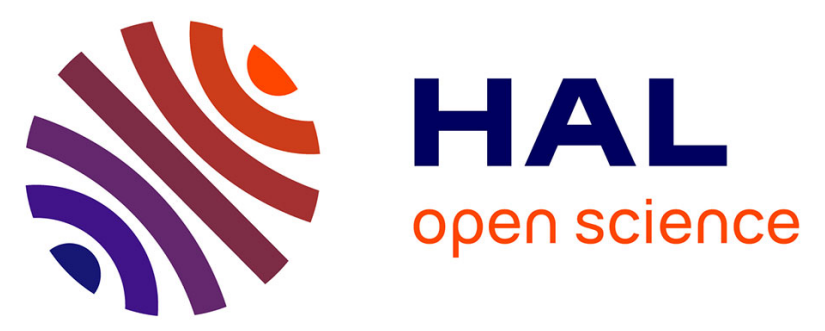

\title{
A simple and rapid method for the disruption of Staphylococcus aureus, optimized for quantitative reverse transcriptase applications: Application for the examination of Camembert cheese
}

Wilfried Ablain, Sylvie Hallier Soulier, David Causeur, Florence Baron

\section{To cite this version:}

Wilfried Ablain, Sylvie Hallier Soulier, David Causeur, Florence Baron. A simple and rapid method for the disruption of Staphylococcus aureus, optimized for quantitative reverse transcriptase applications: Application for the examination of Camembert cheese. Dairy Science \& Technology, 2009, 89, pp.6981. $10.1051 /$ dst/2008034 . hal-01454051

\author{
HAL Id: hal-01454051 \\ https://hal.science/hal-01454051
}

Submitted on 31 May 2020

HAL is a multi-disciplinary open access archive for the deposit and dissemination of scientific research documents, whether they are published or not. The documents may come from teaching and research institutions in France or abroad, or from public or private research centers.
L'archive ouverte pluridisciplinaire HAL, est destinée au dépôt et à la diffusion de documents scientifiques de niveau recherche, publiés ou non, émanant des établissements d'enseignement et de recherche français ou étrangers, des laboratoires publics ou privés. 


\title{
A simple and rapid method for the disruption of Staphylococcus aureus, optimized for quantitative reverse transcriptase applications: Application for the examination of Camembert cheese
}

\author{
Wilfried Ablain ${ }^{1,2,3}$, Sylvie Hallier SoUlier ${ }^{3}$, David CAUSEUR ${ }^{4}$, \\ Michel GAUTIER ${ }^{1,2}$, Florence BARON ${ }^{1,2 *}$ \\ ${ }^{1}$ Agrocampus Ouest, Laboratoire de Microbiologie Alimentaire, 65 rue de Saint-Brieuc, \\ 35042 Rennes Cedex, France \\ ${ }^{2}$ INRA, UMR1253, Laboratoire de Science et Technologie du Lait et de l'Euf, \\ 65 rue de Saint-Brieuc, 35042 Rennes Cedex, France \\ ${ }^{3}$ Genesystems, 1 rue du Courtil, Centre CICEA, 35170 Bruz, France \\ ${ }^{4}$ Agrocampus Ouest, Laboratoire de Mathématiques Appliquées, 65 rue de Saint-Brieuc, \\ 35042 Rennes Cedex, France
}

Received 17 April 2008 - Accepted 21 October 2008

\begin{abstract}
Transcriptomic studies of microorganisms are dependent upon the efficiency of the RNA extraction procedure. In this study, we compared different methods used to disrupt bacterial cells that are frequently described in the literature, such as mechanical (sonication, bead beating) and enzymatic (lysozyme or lysostaphin digestion) disruption. Factorial designs and ANOVA procedures were used to compare statistically the efficiency of these protocols on Staphylococcus aureus. The results were assessed in terms of quality and quantity of RNA extract suitable for further quantitative reverse transcriptase PCR (qRT-PCR) analysis. We selected a simple, rapid (in less than four hours) and sensitive RNA extraction/purification protocol based on lysostaphin treatment, followed by a bead-beating procedure. This method allowed an excellent recovery $(>85 \%)$ of $16 \mathrm{~S}$ rRNA from over a wide range of CFU $\left(10^{9}\right.$ to $\left.10^{2} \mathrm{CFU} \cdot \mathrm{mL}^{-1}\right)$, efficient on different $S$. aureus strains in both exponential and stationary growth phases in pure culture. Application of the protocol for the examination of artificially contaminated Camembert cheese achieved sensitivities of $1.1 \times 10^{2}$ copies of the 16S rRNA gene $\cdot \mathrm{g}^{-1}$ of cheese. This protocol constitutes an essential tool for gene expression studies of $S$. aureus in Camembert cheese.
\end{abstract}

Staphylococcus aureus / cell lysis / RNA extraction / qRT-PCR / Camembert cheese

摘要 - Camembert 干酪中 Staphylococcus aureus 细胞破碎及定量分析。RNA 提取的 效率是微生物转录组学研究的基础。本研究比较了几种常用的细胞裂解方法, 如机械 裂解法 (超声波破碎法、玻璃珠破碎法) 和酶裂解法 (如溶菌酶或溶葡萄球菌酶裂解 法) 对 Staphylococcus aureus 细胞裂解的效率。因子设计和方差分析被用于统计分析比 较不同细胞裂解方法的裂解效率。以提取的 RNA 适用于进一步定量 RT-PCR 分析的数 量和质量, 对结果进行评定。选定了一个简便、快速 (少于 $4 \mathrm{~h}$ ) 的 RNA 提取/纯化方法,

* Corresponding author (通讯作者): florence.baron@agrocampus-ouest.fr 
该方法以溶葡萄球菌酶裂解细胞后, 进行玻璃珠破碎, 二者相结合进行有效的细胞裂解。此 方法对于较大范围的 CFU $\left(10^{9}-10^{2} \mathrm{CFU} \cdot \mathrm{mL}^{-1}\right)$ 均显示出卓越的回收效率 (85\%)。同时此方 法对不同菌株及处于不同生长时期（如对数生长期和稳定期）的同一菌株均适用。用此方 法对人为加入 S. aureus 的干酪检测, 灵敏度可达到每克干酪中 $1.1 \times 10^{2} 16 \mathrm{~S}$ rRNA 基因的拷 贝数。此方法是研究 Camembert 干酪中 S. aureus 基因表达的基本工具。

\section{Staphylococcus aureus / 细胞裂解 / RNA提取 / 定量RT-PCR / Camembert 干酪}

Résumé - Mise au point d'une méthode rapide et simple de lyse de Staphylococcus aureus, optimisée pour une analyse par RT-PCR en temps réel : Application à l'examen de camembert. Le succès de l'étude du transcriptome d'un microorganisme dépend de l'efficacité de l'extraction des ARN. Par cette étude, nous avons comparé différentes méthodes fréquemment rencontrées dans la littérature pour lyser les bactéries telles que les lyses mécaniques (sonication, bead beating) et enzymatiques (digestion au lysozyme ou à la lysostaphine). L'utilisation de plans d'expérience a permis de comparer statistiquement l'efficacité des différents protocoles sur Staphylococcus aureus. Les résultats sont comparés selon la qualité et la quantité des ARN extraits, par reverse transcriptase PCR quantitative (qRT-PCR). Nous avons sélectionné un protocole d'extraction/purification des ARN, simple, rapide (en moins de quatre heures) et sensible, basé sur une digestion à la lysostaphine suivie d'un cassage par billes. Cette méthode permet une excellente récupération (> $85 \%)$ de l'ARNr $16 \mathrm{~S}$ à partir d'une large gamme d'UFC $\left(10^{9}\right.$ à $\left.10^{2} \mathrm{UFC} \cdot \mathrm{mL}^{-1}\right)$, et est efficace sur différentes souches de $S$. aureus en culture pure, en phase exponentielle ou stationnaire de croissance. L'application du protocole pour l'examen d'un camembert artificiellement contaminé permet de détecter jusqu'à $1.1 \times 10^{2}$ copies d'ARNr $16 \mathrm{~S} \cdot \mathrm{g}^{-1}$ de fromage. Ce protocole constitue un outil essentiel pour l'étude de l'expression des gènes de $S$. aureus en matrice camembert.

Staphylococcus aureus / lyse cellulaire / extraction d'ARN / RT-PCR quantitative / camembert

\section{INTRODUCTION}

During the past few years, transcriptomic studies using quantitative reverse transcriptase PCR (qRT-PCR) have been developed considerably to study bacterial comportment, virulence and drug resistance.

One of the main hurdles to qRT-PCR is the recovery of total RNA directly from the sample. Indeed, if the efficient recovery of RNA extract in large amount is essential, the purity and integrity of RNA are critical elements for the overall success of RNA-based analyses [15]. The extraction and purification procedure of total RNA requires the recovery of high-quality RNA that is undegraded, and free of: proteins, DNA, inhibitors for RT and real-time PCR reaction, and nucleases to further qRT-PCR studies [9].

A variety of methods have been developed for the preparation of cell-free extracts, such as mechanical (sonication, blending or bead beating) and enzymatic (lysozyme or lysostaphin digestion) disruption of the bacterial cells $[2,4,6,12,16$, $17,21]$. These procedures have been used successfully with a variety of microorganisms and culture conditions.

In our work, we evaluated the effects of different methods, applied for bacterial lysis. The study was carried out on Staphylococcus aureus, which is known to be very difficult to disrupt. Moreover, Staphylococcus aureus is considered an important pathogen due to a combination of toxin-mediated virulence, invasiveness and antibiotic resistance. This bacterium is involved in nosocomial infections and in food poisoning. Consumption of foods containing this microorganism is often identified as the cause of illness. Intoxication is characterized by vomiting and diarrhea resulting from the ingestion of foods or beverages containing one or more preformed enterotoxins produced by Staphylococcus aureus $[9,14]$. 
The aim of this study was to select a simple, rapid and efficient lysis protocol usable for the study of RNA content of S. aureus by qRT-PCR.

\section{MATERIALS AND METHODS}

\subsection{Bacterial strains, culture conditions and sample preparation}

Ten $S$. aureus strains were used: 3 laboratory strains (RN 4220, Mu50 and N315), 2 isolated from humans (CHU Rennes) and 5 from milk products (milk and cheese). Only the RN4220 strain was used for RNA extraction optimizations.

All strains were stored at $-80{ }^{\circ} \mathrm{C}$ in Tryptone Soy Broth (TSB, AES, Combourg, France) supplemented with $15 \%$ (vol/vol) glycerol. For all experiments, an overnight culture was prepared from frozen bacterial stock in $5 \mathrm{~mL}$ of TSB at $37{ }^{\circ} \mathrm{C}$, and the subcultures were grown after $1 / 100$ dilution in TSB with shaking $(250 \mathrm{rpm})$ at $37^{\circ} \mathrm{C}$. Population levels were enumerated on Tryptone soy agar (TSA, AES) after $24 \mathrm{~h}$ of incubation at $37^{\circ} \mathrm{C}$.

For optimization of lysis procedures, $2.5 \mathrm{~mL}$ of culture were added to 2 volumes of RNA protect bacteria reagent (Qiagen Inc., Courtabœuf, France). After vortexing $(30 \mathrm{~s})$, the mixture was incubated at room temperature ( $5 \mathrm{~min}$ ) and then diluted tenfold in sterile Tryptone salt (TS, (Tryptone $1 \mathrm{~g} \cdot \mathrm{L}^{-1}$, Sodium Chloride $8.5 \mathrm{~g} \cdot \mathrm{L}^{-1}$ ), AES Laboratoires, Combourg, France).

One-hundred-microliter aliquots containing $10^{6}$ bacteria were snap-frozen in liquid nitrogen and stored at $-80{ }^{\circ} \mathrm{C}$ before analysis. For the sensitivity studies, the aliquots were diluted in tryptone salt to achieve the required bacteria level before lysis.

\subsection{Food sample analysis}

Twenty-five grams of French Camembert (local supermarket) were homogenized (45 s) with $225 \mathrm{~mL}$ of buffered-saline peptone water (AES) in a Stomacher 400 (Seward, London, UK). Fifty-milliliteraliquots of homogenate were inoculated with $2 \mathrm{~mL}$ of varying dilutions of strain RN4220 (log phase) or TS (negative control). After centrifugation at $5500 \times g$ for $5 \mathrm{~min}$ at $4{ }^{\circ} \mathrm{C}$, the pellet was washed three times with Chelex 25\% (w/v; SigmaAldrich Co., Missouri, USA). The final pellet (containing bacteria and Chelex beads) was resuspended in $100 \mu \mathrm{L}$ of TE $1 \mathrm{X}$ (TrisHCl $10 \mathrm{mmol} \cdot \mathrm{L}^{-1}$; EDTA $1 \mathrm{mmol} \cdot \mathrm{L}^{-1}$ ) and then used for RNA or DNA extraction, as described below.

\subsection{Lysis protocol}

In this study, three extraction techniques were compared in terms of DNA and RNA extraction yield: enzymatic treatment, sonication and bead-beating homogenization. The experiments were carried out according to the experimental design procedures described in Table I.

\subsubsection{Enzymatic digestion}

Incubation time and the enzymatic concentration were tested for two different enzymes (lysozyme and lysostaphin, SigmaAldrich Co.). Ten microliters of enzymatic solution (concentrations are given in Tab. I) were added to $100 \mu \mathrm{L}$ of frozen bacteria aliquots and incubated at $37^{\circ} \mathrm{C}$ for 15,30 or $45 \mathrm{~min}$.

\subsubsection{Sonication}

Two parameters were evaluated: the volume of cellular suspension and the sonication time. Volumes of 350, 525 or $700 \mu \mathrm{L}$ of lysis buffer (see DNA and RNA purification procedure) were added to $100 \mu \mathrm{L}$ 
W. Ablain et al.

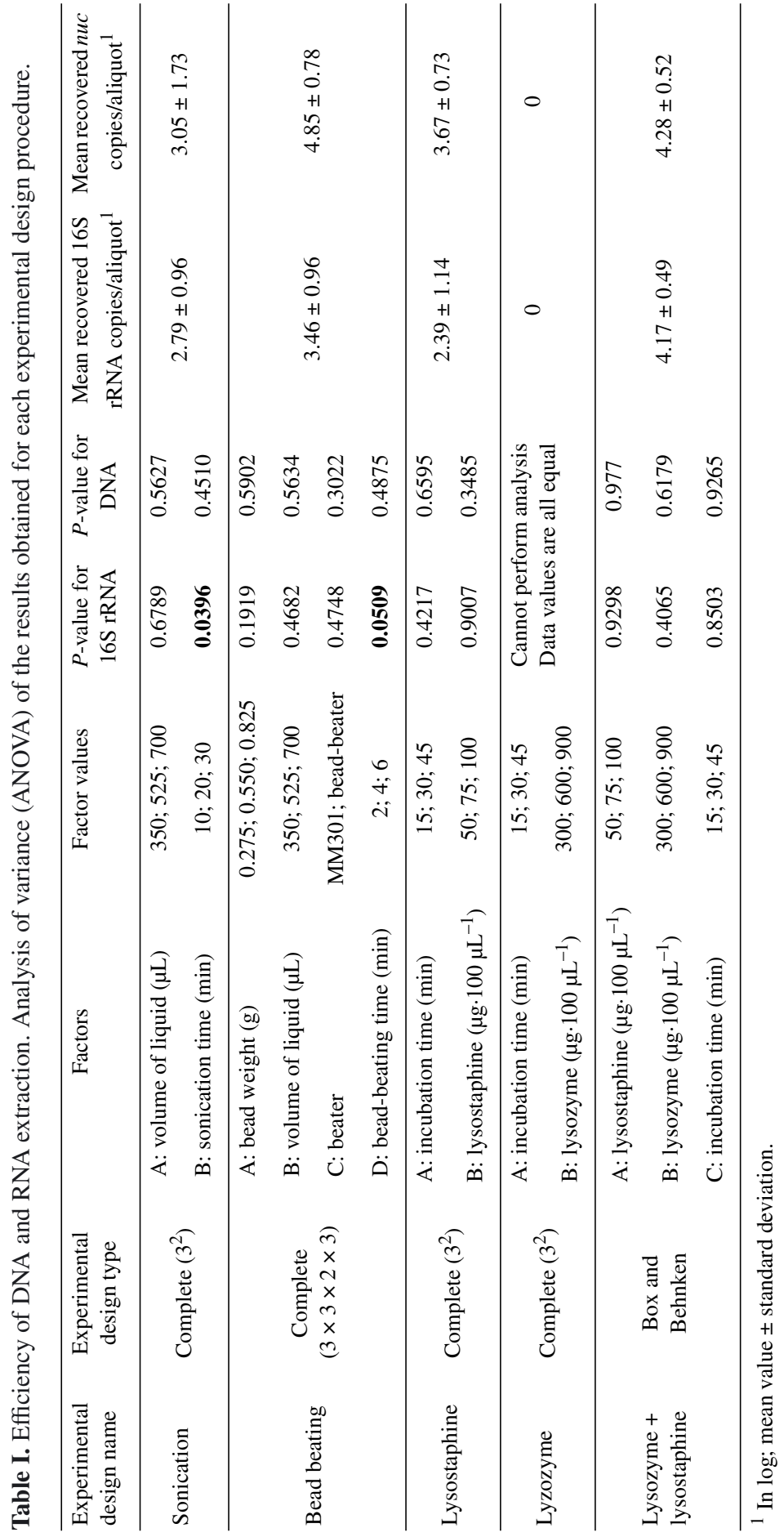


of defrosted bacteria aliquots and sonicated for 10,20 or $30 \mathrm{~min}$ at $20{ }^{\circ} \mathrm{C}$ in a 20-liter sonication bath (88170 Bioblock Scientific).

\subsubsection{Bead beating}

Four parameters were tested: the volume of cellular suspension, the quantity of beads, the bead-beating time and the supplier of the beater. Volumes of 350, 525 or $700 \mu \mathrm{L}$ of corresponding lysis buffer (see DNA and RNA purification procedure) and $0.275,0.550$ or $0.825 \mathrm{mg}$ of acidwashed zirconium beads (Sigma-Aldrich Co.) were added to $100 \mu \mathrm{L}$ defrosted bacteria aliquot, then bead-beaten for 2,4 or $6 \mathrm{~min}$. The preparations were treated by alternating 1-min cycles of beating with incubation on ice for $2 \mathrm{~min}$. Two different beaters were tested: the MM301 (Qiagen) at $30 \mathrm{~Hz}$, and the Beadbeater cell disrupter (Biospec Products; Bartlesville, Oklahoma), at $3200 \mathrm{rpm}$ speed.

\subsubsection{Experimental design}

For each lysozyme and lysostaphin digestion, and for sonication and beadbeating protocols, the lysis was performed according to a complete factorial design. For simultaneous lysostaphin and lysozyme digestion, a Box-Behnken design [7] was used. The order of the experiments was randomized for each protocol. Each experimental design was performed only once.

DNA and RNA quantity and quality were taken into account to evaluate the performance of the lysis protocols.

\subsection{DNA and RNA purification procedure}

Bacterial genomic DNA and total RNA were purified using the Nucleospin DNA plant L kit or the Nucleospin RNA II minikit (Macherey-Nagel
GmbH \& Co. KG, Düren, Germany) according to the manufacturer's recommendations, but modified as follows, before the lysate clarification state: the crude lysates were completed at $700 \mu \mathrm{L}$ with $\mathrm{C} 4$ solution/EtOH (vol/vol) mix or with RA1 solution/beta-mercapto-ethanol mix for the DNA and RNA protocol, respectively. The elution was performed in a $200-\mu \mathrm{L}$ or $60-\mu \mathrm{L}$ one-step procedure for DNA and RNA, respectively. After elution, the samples were frozen immediately and stored at $-80{ }^{\circ} \mathrm{C}$ until use. Contaminating genomic DNA was removed from total RNA using the DNA-free kit (Ambion, Austin, Texas, USA), according to the manufacturer's recommendations. The absence of DNA in RNA extracts was assessed by real-time PCR targeting of the $16 \mathrm{~S}$ rRNA gene.

\subsection{Oligonucleotide primers and probes used}

S. aureus-specific oligonucleotides and fluorogenic probes (Tab. II), targeting the пис single-copy gene and the $16 \mathrm{~S}$ rRNA 5-copy gene were designed on the basis of the Mu50 strain gene (accession number ID: 158878) with Primer Express, software version 2.0 (Applied Biosystems, Foster City, California, USA). Our primers and probes specifically distinguished $S$. aureus strains from nontarget bacteria, as assessed on 10 staphylococcal (strains RN4220; LMA1049; LMA1053; LMA1054; LMA1093; LMA1094; LMA1095; LMA1177; LMA1178; Mu50) and 13 "non-staphylococcal" strains (Pseudomonas aeruginosa; Escherichia coli; Klebsellia oxytoca; Klebsellia pneumoniae; Enterococcus faecalis; Enterococcus faecium CIP; Enterococcus durans; Streptococcus bovis; Streptococcus equinus; Listeria monocytogenes EfGDe; Salmonella enteritidis; Bacillus cereus; Yersinia enterocolitica) and 
Table II. Oligonucleotides used for both real-time PCR and qRT-PCR assays.

\begin{tabular}{lcccc}
\hline Target gene & Accession $\mathrm{n}^{\circ}$ & Name & Type & Sequence \\
\hline nuc & gil46623 & nuc SaQfor & Forward primer 5'-ATG GAC GTG GCT TAG CGT AT-3' \\
& & nuc SaQrev & Reverse primer & 5'-TGA CCT GAA TCA GCG TTG TC-3' \\
& & nuc SaQp & Taqman probe & 5'-TCG TCA AGG CTT GGC TAA AGT TGC-3' \\
16S rRNA & gil1121873 & 16S SaQfor & Forward primer & 5'-CCG TCA CAC CAC GAG AGT TT-3' \\
& & 16S SaQrev & Reverse primer & 5'-TTA CGA CTT CAC CCC AAT CA-3' \\
& 16S SaQp & Taqman probe & 5'-CCG AAG CCG GTG GAG TAA CCT T-3' \\
\hline
\end{tabular}

one "non-S. aureus" (Staphylococcus epidermidis) strain (data not shown).

\subsection{Real-time PCR conditions}

The assays were performed in duplicate with a $20-\mu \mathrm{L}$ real-time PCR amplification mixture containing $15 \mu \mathrm{L}$ of PCR mix (1 X Taq DNA polymerase buffer (Qiagen Inc., Valencia, California, USA), $2.5 \mathrm{mmol} \cdot \mathrm{L}^{-1}$ $\mathrm{MgCl}_{2}$ (Sigma-Aldrich), $200 \mu \mathrm{mol} \cdot \mathrm{L}^{-1}$ dNTPs mix (Sigma-Aldrich), $0.4 \mu \mathrm{mol} \cdot \mathrm{L}^{-1}$ forward and reverse primers, $0.2 \mu \mathrm{mol} \cdot \mathrm{L}^{-1}$ fluorogenic FAM-TAMRA-labeled probe, $0.1 \%$ BSA (w/w) (Sigma-Aldrich), $0.01 \%$ Tween 20 (w/w), 0.75 U Taq DNA polymerase (Qiagen) and $5 \mu \mathrm{L}$ DNA or cDNA. Reactions were done with an iCycler apparatus (Bio-Rad Laboratories, California, USA) with the following program: $4 \mathrm{~min}$ at $95{ }^{\circ} \mathrm{C}$, followed by 46 cycles of $15 \mathrm{~s}$ at $95^{\circ} \mathrm{C}$ and $45 \mathrm{~s}$ at $57^{\circ} \mathrm{C}$ (nuc gene phase) or $58^{\circ} \mathrm{C}$ (16S rRNA gene phase).

The standard curves were generated by using tenfold dilution series $\left(2.44 \times 10^{0}\right.$ to $2.44 \times 10^{4}$ genome units (GU)/well) of genomic DNA. Purified genomic DNA solution $\left(3.10^{8} \mathrm{GU} \cdot \mathrm{mL}^{-1}\right)$ was quantified using PicoGreen (Molecular Probes, Eugene, Oregon, USA) in a luminescence spectrometer LS50B (Perkin-Elmer, Norwalk, Connecticut, USA), and diluted to the working concentration in double-distilled water. The corresponding genome units number was calculated on the basis of the size of the $S$. aureus genome [13]: one molecule of genomic DNA corresponded to $3.23 \mathrm{fg}$ of DNA. All reactions were performed in duplicate. The 95\% confidence interval was calculated for each serial dilution, according to a binomial distribution $[11,18]$ by using the STATGRAPHICS Plus software, version 5.0 (Chicago, Illinois, USA).

\subsection{Quantitative Reverse Transcriptase PCR (qRT-PCR)}

Quantitative RT-PCRs were conducted in two-step reactions using the iCycler (Bio-Rad). SuperScript II reverse transcriptase (Invitrogen, Carlsbad, California, USA) was used to produce single-strand cDNA from $5 \mu \mathrm{L}$ of purified total RNA according to the supplier's instructions. The cDNA synthesis was primed by the $16 \mathrm{~S} \mathrm{SaQrev} \mathrm{primer} \mathrm{(Tab.} \mathrm{II)} \mathrm{at} 42{ }^{\circ} \mathrm{C}$ for $50 \mathrm{~min}$.

\subsection{Statistical analysis}

For each lysis protocol, RNA quantity and quality were measured by realtime RT-PCR, while DNA quantity and quality were measured by real-time PCR. The STATGRAPHICS Plus 5.0 software (Chicago, Illinois, USA) was used for all statistical analyses for RNA and DNA quantities. Multiple group comparisons were made using analysis of variance (ANOVA). 
Table III. Chosen protocols and results of lysis optimization. All the MM301 bead-beating protocols were ordered firstly in terms of purified RNA amount and secondly in term of purified DNA amount. Only the eight first classified protocols were considered for the lysis optimization study.

\begin{tabular}{ccccccccc}
\hline & & & \multicolumn{5}{c}{ LogSQ RNA/starting tube $^{1}$} & LogSQ DNA/starting tube \\
\hline Protocol & $\begin{array}{c}\text { Bead } \\
\text { weight } \\
(\mathrm{g})\end{array}$ & $\begin{array}{c}\text { Volume } \\
\text { of liquid } \\
(\mu \mathrm{L})\end{array}$ & $\begin{array}{c}\text { Beater } \\
\text { Bend-beating }\end{array}$ & $\begin{array}{c}\text { Beadhout } \\
\text { time } \\
(\mathrm{min})\end{array}$ & $\begin{array}{c}\text { With } \\
\text { pretreatment }\end{array}$ & $\begin{array}{c}\text { Without } \\
\text { pretreatment } \\
\text { pretreatment }\end{array}$ & $\begin{array}{c}\text { With } \\
\text { pretreatment }\end{array}$ \\
\hline 1 & 0.275 & 700 & MM301 & 4 & 4.97 & 5.47 & 5.21 & 6.02 \\
2 & 0.550 & 350 & MM301 & 4 & 4.46 & 5.38 & 5.38 & 5.73 \\
3 & 0.550 & 700 & MM301 & 4 & 4.46 & 5.38 & 4.96 & 5.72 \\
4 & 0.825 & 350 & MM301 & 6 & 3.99 & 5.33 & 5.56 & 5.78 \\
5 & 0.550 & 350 & MM301 & 6 & 3.99 & 5.23 & 4.89 & 5.93 \\
6 & 0.550 & 525 & MM301 & 4 & 3.96 & 4.97 & 5.52 & 6.16 \\
7 & 0.275 & 350 & MM301 & 4 & 3.93 & 4.96 & 5.13 & 5.94 \\
8 & 0.550 & 700 & MM301 & 6 & 3.73 & 4.56 & 4.81 & 5.64 \\
\hline
\end{tabular}

${ }^{1}$ Estimated by Q-PCR and RT-Q-PCR before lysis optimization.

\section{RESULTS}

\subsection{Sensitivity and quantification of the real-time PCR assays}

The capacity of the real-time PCR method to determine accurately the number of targets (DNA gene copies) present in the sample was assessed. As few as 2.4 target molecules (12 for $16 \mathrm{~S}$ rRNA) per well could be detected with $90 \%$ probability, and constituted the detection limit value (DL $\mathrm{DLc}_{\text {nuc }}$ or $\mathrm{DL}_{16 \mathrm{~S}}$ ). Positive amplification and accurate quantification $( \pm 0.14 \log )$ were achieved in $100 \%$ of the replicates when 24 or more target molecules were present (120 for 16S rRNA), and constituted the quantification limit value $\left(\mathrm{QL}_{\mathrm{nuc}}\right.$ or $\mathrm{QL}_{16 \mathrm{~S}}$ ) (note that the nuc gene is in monocopy in the $S$. aureus genome and that $16 \mathrm{~S}$ rRNA is present in 5 copies).

The relationship between the initial number of $S$. aureus DNA molecules and Threshold Cycle values (TC) was linear down to 24 (nuc) and 12 (16S rRNA) target molecules, as indicated by the regression coefficient obtained $\left(R^{2}=0.997\right)$. The calculated slopes (-3.621, пис; -3.419 , $16 \mathrm{~S}$ rRNA) indicated that our real-time PCR systems were highly linear and that reliable quantification was possible within this interval.

\subsection{Comparison of the lysis protocols}

Real-time PCR results allowed assessment of the lysis efficiency, while qRTPCR results provided information about the RNA quality.

Table I summarizes the results of the ANOVA analysis for each experimental procedure. For sonication, bead beating and enzymatic lysis, none of the factors have a statistically significant effect on the quantity of detected DNA at the $95 \%$ confidence level. Nevertheless, the average quantity of DNA (GU/bacterial frozen aliquot) obtained with the bead-beating lysis protocol was higher than that obtained by the other protocols tested (Tab. I) but remained inferior to the initial quantity $(4.85 \pm 0.78 \log \mathrm{GU} /$ aliquot versus $6 \log$ GU/aliquot).

With regards to the RNA quantification for enzymatic lysis, none of the factors had a significant effect $(P<0.05)$ on the quantity of detected RNA. For sonication lysis and for bead-beating lysis, the variance 
of time had a statistically significant effect $(P<0.05)$ on the detected quantity of RNA (Tab. I). In fact, for sonication lysis, a procedure time of $10 \mathrm{~min}$ was significantly $(P<0.05)$ more effective, while a procedure time of 4 min was significantly more effective $(P<0.05)$ for bead beating. The average quantity of RNA (16S rRNA copies/bacterial frozen aliquots) obtained for a bead-beating time of $4 \mathrm{~min}(3.9 \pm$ $0.52 \mathrm{log}$ ) was higher than that obtained with $10 \mathrm{~min}$ of sonication $(3.4 \pm 0.39 \mathrm{log})$, suggesting that bead-beating lysis was better for RNA extraction (data not shown).

For lyzosyme lysis, regardless of the tested conditions, no DNA or RNA was detectable by real-time PCR or qRT-PCR, respectively, suggesting that lyzosyme was not effective for digestion of the staphylococcal cell wall.

Concerning both real-time PCR and qRT-PCR signals, bead-beating lysis appeared to be the most effective protocol, but did not allow $100 \%$ lysis efficiency. These results suggest that the conditions for this lysis procedure have to be improved.

\subsection{Effect of lysostaphin pretreatment on the bead-beating lysis efficiency}

In order to improve the bead-beating procedure, we studied the effect of enzymatic pretreatment on bead-beating lysis efficiency. Since the type of beater did not have a statistically significant effect on the quantity of either RNA or DNA, we selected the MM301 beater for the study, which permitted more analyses to be conducted at the same time. Since none of the factors tested for lysostaphin lysis had a statistically significant effect $(P>0.05)$ on the quantity of detected DNA and RNA (Tab. I), we chose both the lowest dose and the shortest incubation time. The chosen protocols are summarized in
Table III. ANOVA analysis showed that lysostaphin pretreatment significantly $(P=$ 0.001) improved bead-beating lysis efficiency for all protocols tested (using $10^{6}$ bacteria frozen aliquots). On average, the increase in amount was approximately 0.7 $\log$ for DNA $(5.86 \pm 0.18 \log$ of nuc copies/aliquot with lysostaphin pretreatment versus $5.16 \pm 0.31 \log$ without) and $1 \log$ for RNA $(5.17 \pm 0.27 \log$ of 16S rRNA copies/aliquot with lysostaphin pretreatment versus $4.21 \pm 0.45 \log$ without) (Tab. III). With regards to RNA quantities, protocol 2 appeared to be statistically the most efficient for RNA extraction (Student's $t$-test $P=0.05$ ) (data not shown). Hence, this protocol was selected for the next study.

\subsection{Protocol efficiency with different staphylococcal strains and growth states}

The efficiency of the selected protocol was tested with 10 different staphylococcal strains (in the stationary state). For one strain (RN4220), 2 different growth states were studied. The protocol was efficient for all the strains for both DNA and RNA extractions (data not shown). The mean recovery rates were $92.4 \pm 12.5 \%$ for DNA and $67.4 \pm 19.8 \%$ for RNA, respectively (as determined by relating GU or $16 \mathrm{~S}$ rRNA copy numbers to $\mathrm{CFU} \cdot \mathrm{mL}^{-1}$ ). For strain RN4220, the DNA recovery rate obtained for exponential $(103.2 \pm 1.1 \%)$ and stationary $(104.0 \pm 1.3 \%)$ growth phases showed that lysis was equally efficient for both states $(P<0.001)$. Nevertheless, for the RNA quantity, a significant $(P<0.05)$ difference $(32.3 \pm 4.7 \%$ versus $122.7 \pm$ $15.5 \%$ ) could be observed, suggesting that 16S rRNA was more abundant in the microbial cell during its exponential state than its stationary phase. 


\subsection{Sensitivity of the optimal protocol}

The sensitivity of the lysis protocol assay was investigated by using different initial quantities of strain RN4220 in the exponential phase. The results are summarized in Table IV. For the qRT-PCR assays, the overall quantification limit was $5.5 \times 10^{3} \mathrm{CFU} \cdot \mathrm{mL}^{-1}$ (i.e. $1.15 \times 10^{1}$ equivalent GU/PCR), and the detection limit value was tenfold inferior. The linear regression analysis of $\mathrm{CT}$ values related to bacterial numbers in the reactions yielded a $R^{2}$ value of 0.999 with a slope similar $(-3.45)$ to that obtained with purified genomic DNA (-3.41), indicating that our qRT-PCR assays accurately quantified $S$. aureus $16 \mathrm{~S}$ rRNA on the interval. Furthermore, these results suggested that our protocol could be applied to gene expression level studies with as little as $5.5 \times$ $10^{3} \mathrm{CFU} \cdot \mathrm{mL}^{-1}$.

\subsection{Food sample analysis}

The ability of our procedure to detect $S$. aureus $16 \mathrm{~S}$ rRNA in Camembert cheese was evaluated. The results showed successful amplification in all the contaminated cheese samples, while no signal was detected in uninoculated foods (Tab. IV). The 16S rRNA amplicon was detected down to concentrations of $1.1 \times 10^{2}$ copies of $16 \mathrm{~S}$ rRNA $\cdot \mathrm{g}^{-1}$ of Camembert (i.e. $1.15 \times 10^{1}$ equivalent GU/PCR when $5 \mathrm{~g}$ of cheese are analyzed), and $1.1 \times 10^{3}$ copies of $16 \mathrm{~S}$ rRNA.g ${ }^{-1}$ were quantified with $63 \%$ of accuracy.

\section{DISCUSSION}

In the literature, lysis protocols are usually described for RNA extraction from Gram-positive bacteria, but the particular conditions of the tests are different from those encountered in diagnostics. In order to select the most efficient protocol, we tested different protocols using five screening experimental design procedures: sonication, lysostaphin and/or lysozyme lysis, and bead beating in conditions frequently described in the literature. The results obtained by enzymatic lysis confirmed that $S$. aureus was completely resistant to lysozyme, as previously demonstrated by Bera et al. $[1,3]$. On the other hand, the lysostaphin lysis appeared largely efficient in releasing nucleic acids from $S$. $a u$ reus, for both real-time PCR and qRT-PCR applications. Nevertheless, the lysostaphin lysis was not complete. Indeed, the number of nuc copies detected (4.67 $\log \mathrm{GU} \cdot \mathrm{mL}^{-1}$ ) did not reach the number of cells subjected to the disruption $\left(7 \log \mathrm{GU} \cdot \mathrm{mL}^{-1}\right)$.

For the combined lysozyme and lysostaphin lysis, the yield of extracted nucleic acid was slightly better than that obtained for lysostaphin lysis alone. These results showed that lyzosyme potentates the lysostaphin anti-staphylococcal activity, as previously observed by Cisani et al., but the effects of lyzozyme are quite weak [10]. Two mechanical disruptions were also tested: sonication and bead-beating methods. The sonication procedure was not very effective for either DNA or RNA extraction. The use of a more complete experimental design, integrating sonication generator power and the ultra-sound frequency could allow for optimization of this lysis [16]. For the bead-beating protocol, a preliminary study showed that zirconium beads were more efficient than glass beads. The bead-beating procedure appeared to be the most efficient for DNA and RNA extraction; however, lysis was not complete, suggesting that the bead-beating protocol requires further optimization. Note that both mechanical disruption methods presented an optimum recovery rate for $16 \mathrm{~S}$ rRNA, using the minimal experimental conditions (time, power, etc.). Longer disruption treatments 
W. Ablain et al.

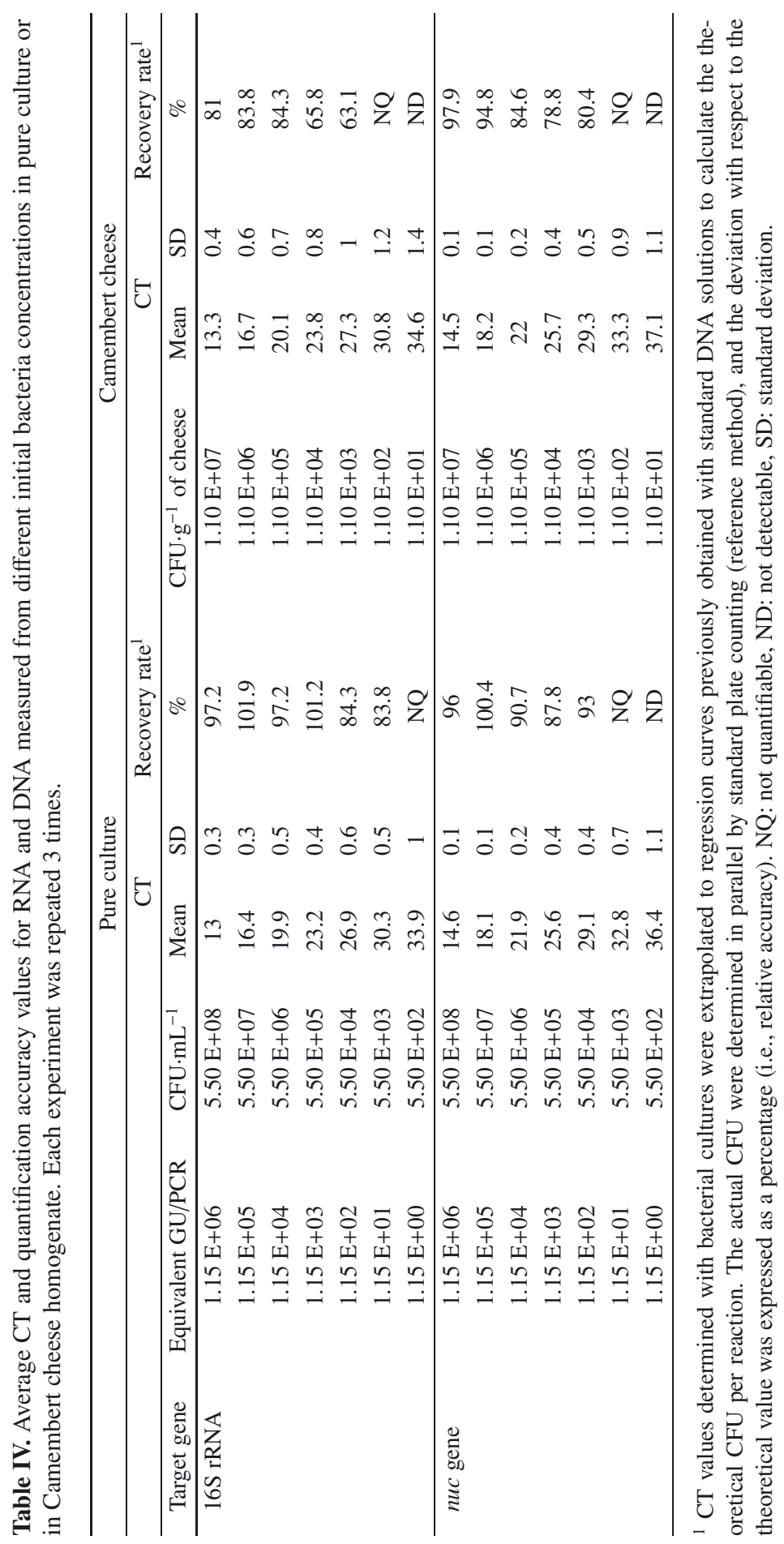


decreased the $16 \mathrm{~S}$ rRNA yield. This could be due to $16 \mathrm{~S}$ rRNA degradation occuring by stronger lysis treatments.

Lysostaphin pretreatment applied before the bead-beating procedure significantly $(P$-value $=0.05)$ improved the nucleic acid yield. Moreover, the studies using different staphylococcal strains demonstrated that our protocol was effective for DNA and RNA recovery for all the strains tested. Our protocol was equally effective for the two physiological states tested: cells collected from exponential or stationary growth states. Furthermore, there were fourfold more copies of $16 \mathrm{~S}$ rRNA detectable in log phase bacteria than in stationary phase bacteria. These results are in agreement with those obtained by Vandecasteele et al. [19, 20], who showed that the ratio $\mathrm{CDNA} / \mathrm{CFU}$ for $16 \mathrm{~S}$ rRNA was 25 during the exponential phase for S. epidermidis and was 3 during the stationary phase.

The most challenging aspect of designing methods for the detection of foodborne pathogens is the achievement of a low detection limit. This goal is of particular importance for $S$. aureus, which is often present in low numbers in food products [1]. Transcriptomic studies of pathogen bacteria by qRT-PCR require extraction of bacterial total RNA content. Actually, the accuracy of gene expression evaluation is recognized to be influenced by the quantity and quality of starting RNA. The qRTPCR results were very similar to the quantitative results obtained by the plate count method over a five log range of CFU. This indicated that our method allowed an accurate quantification of $S$. aureus $16 \mathrm{~S}$ rRNA at concentrations as low as $5.5 \times$ $10^{3} \mathrm{CFU} \cdot \mathrm{mL}^{-1}$ (i.e. $1.15 \times 10^{1}$ equivalent GU/PCR) in broth cultures, while the sensitivity was reduced by ten in Camembert cheese $\left(1.1 \times 10^{3} \mathrm{CFU} \cdot \mathrm{g}^{-1}\right.$ of Camembert, i.e. $1.15 \times 10^{2}$ equivalent GU/PCR). Note that $50 \mathrm{~mL}$ of homogenate (corresponding to $5 \mathrm{~g}$ of cheese) was analyzed versus only $100 \mu \mathrm{L}$ for broth culture samples. In fact, problems in applying a RT-PCR assay to foods can arise from various factors [8] such as the presence of substrates chelating magnesium ions necessary for PCR, degradation of nucleic acids and/or primers by RNases or DNases, and direct inhibition of DNA polymerase and reverse transcriptase. The degree of inhibition is greatly dependent on the type of food. The removal of food components such as proteins, fats and polysaccharides can positively affect the yield and quality of extracted nucleic acids [5]. Therefore, the level of contaminating substances was reduced by the introduction of specific additional steps during the processes of extraction from cheese samples. The lower sensitivity of the assay for Camembert versus pure culture was probably due to a greater loss of cells (and the consequent minor RNA yield), as a result of the more complex extraction procedure required for this kind of sample. Nonetheless, these results demonstrate the suitability of RTPCR for studying the expression of genes of $S$. aureus in Camembert; it could be successfully adopted for use with other foods. However, the method should also be tested on naturally contaminated samples, since distribution and physiology of $S$. aureus in naturally contaminated cheese might be very different, compared with artificially contaminated samples.

Our procedure allows the detection and quantification of 16S rRNA in about $4 \mathrm{~h}$. Using RNA extracts from dilutions of bacteria, the experiments demonstrated a good linear correlation between the total cell number and the fluorescence signals. The accurate quantification of the $16 \mathrm{~S}$ rRNA obtained from food samples showed values lower than the values from pure cultures. However, this difference can be attributed to two additional variables; namely, the food matrix effect and the presence of endogenous microflora. Indeed, the chemical and genetic complexity of the 
naturally contaminated food samples, often associated with a large amount of bacteria, might affect either the quality or the yield of total RNA, or both.

\section{CONCLUSION}

In conclusion, we have developed a simple, rapid (in less than one hour) and sensitive lysis protocol applicable to different $S$. aureus strains. This protocol allowed an extraction of both high quality and large quantity of DNA and RNA, for further realtime PCR and qRT-PCR applications. This protocol could constitute an essential tool for transcriptomic study of $S$. aureus, such as the study of differential RNA content of live or dead bacteria in Camembert.

Acknowledgements: We thank S. Chevalier for competent technical assistance.

\section{REFERENCES}

[1] Alarcon B., Vicedo B., Aznar R., PCR-based procedures for detection and quantification of Staphylococcus aureus and their application in food, J. Appl. Microbiol. 100 (2006) 352-364.

[2] Aldous W.K., Pounder J.I., Cloud J.L., Woods G.L., Comparison of six methods of extracting Mycobacterium tuberculosis DNA from processed sputum for testing by quantitative real-time PCR, J. Clin. Microbiol. 43 (2005) 2471-2473.

[3] Bera A., Herbert S., Jakob A., Vollmer W., Gotz F., Why are pathogenic staphylococci so lysozyme resistant? The peptidoglycan O-acetyltransferase OatA is the major determinant for lysozyme resistance of Staphylococcus aureus, Mol. Microbiol. 55 (2005) 778-787.

[4] Bergh K., Stoelhaug A., Loeseth K., Bevanger L., Detection of group B streptococci (GBS) in vaginal swabs using real-time PCR with TaqMan probe hybridization, Indian J. Med. Res. 119 Suppl. (2004) 221-223.

[5] Bleve G., Rizzotti L., Dellaglio F., Torriani S., Development of reverse transcription
(RT)-PCR and real-time RT-PCR assays for rapid detection and quantification of viable yeasts and molds contaminating yogurts and pasteurized food products, Appl. Environ. Microbiol. 69 (2003) 4116-4122.

[6] Bourrain M., Achouak W., Urbain V., Heulin T., DNA extraction from activated sludges, Curr. Microbiol. 38 (1999) 315-319.

[7] Box G., Behnken D., Some new three-level designs for the study of quantitative variables, Technometrics 2 (1960) 455-475.

[8] Bustin S.A., Absolute quantification of mRNA using real-time reverse transcription polymerase chain reaction assays, J. Mol. Endocrinol. 25 (2000) 169-193.

[9] Bustin S.A., Nolan T., Pitfalls of quantitative real-time reverse-transcription polymerase chain reaction, J. Biomol. Tech. 15 (2004) 155-166.

[10] Cisani G., Varaldo P.E., Grazi G., Soro O., High-level potentiation of lysostaphin anti-staphylococcal activity by lysozyme, Antimicrob. Agents Chemother. 21 (1982) 531-535.

[11] Kay S., Van den Eede G., The limits of GMO detection, Nat. Biotechnol. 19 (2001) 405.

[12] Kocagoz T., Yilmaz E., Ozkara S., Kocagoz S., Hayran M., Sachedeva M., Chambers H.F., Detection of Mycobacterium tuberculosis in sputum samples by polymerase chain reaction using a simplified procedure, J. Clin. Microbiol. 31 (1993) 1435-1438.

[13] Kuroda M., Ohta T., Uchiyama I., Baba T., Yuzawa H., Kobayashi I., Cui L., Oguchi A., Aoki K., Nagai Y., Lian J., Ito T., Kanamori M., Matsumaru H., Maruyama A., Murakami H., Hosoyama A., MizutaniUi Y., Takahashi N.K., Sawano T., Inoue R., Kaito C., Sekimizu K., Hirakawa H., Kuhara S., Goto S., Yabuzaki J., Kanehisa M., Yamashita A., Oshima K., Furuya K., Yoshino C., Shiba T., Hattori M., Ogasawara N., Hayashi H., Hiramatsu K., Whole genome sequencing of meticillin-resistant Staphylococcus aureus, Lancet 357 (2001) 1225-1240.

[14] Le Loir Y., Baron F., Gautier M., Staphylococcus aureus and food poisoning, Genet. Mol. Res. 1 (2003) 63-76.

[15] Lin S.L., Chuong C.M., Widelitz R.B., Ying S.Y., In vivo analysis of cancerous gene expression by RNA-polymerase chain reaction, Nucleic Acids Res. 27 (1999) 4585-4589. 
[16] Middelberg A.P., Process-scale disruption of microorganisms, Biotechnol. Adv. 13 (1995) 491-551.

[17] Rantakokko-Jalava K., Jalava J., Optimal DNA isolation method for detection of bacteria in clinical specimens by broad-range PCR, J. Clin. Microbiol. 40 (2002) 42114217.

[18] Van den Eede G., Kay S., Anklam E., Schimmel H., Analytical challenges: bridging the gap from regulation to enforcement, J. AOAC Int. 85 (2002) 757-761.

[19] Vandecasteele S.J., Peetermans W.E., Merckx R., Van Eldere J., Quantification of expression of Staphylococcus epidermidis housekeeping genes with Taqman quantitative PCR during in vitro growth and under different conditions, J. Bacteriol. 183 (2001) 7094-7101.

[20] Vandecasteele S.J., Peetermans W.E., Merckx R., Van Ranst M., Van Eldere J., Use of gDNA as internal standard for gene expression in staphylococci in vitro and in vivo, Biochem. Biophys. Res. Commun. 291 (2002) 528-534.

[21] Weinrick B., Dunman P.M., McAleese F., Murphy E., Projan S.J., Fang Y., Novick R.P., Effect of mild acid on gene expression in Staphylococcus aureus, J. Bacteriol. 186 (2004) 8407-8423. 